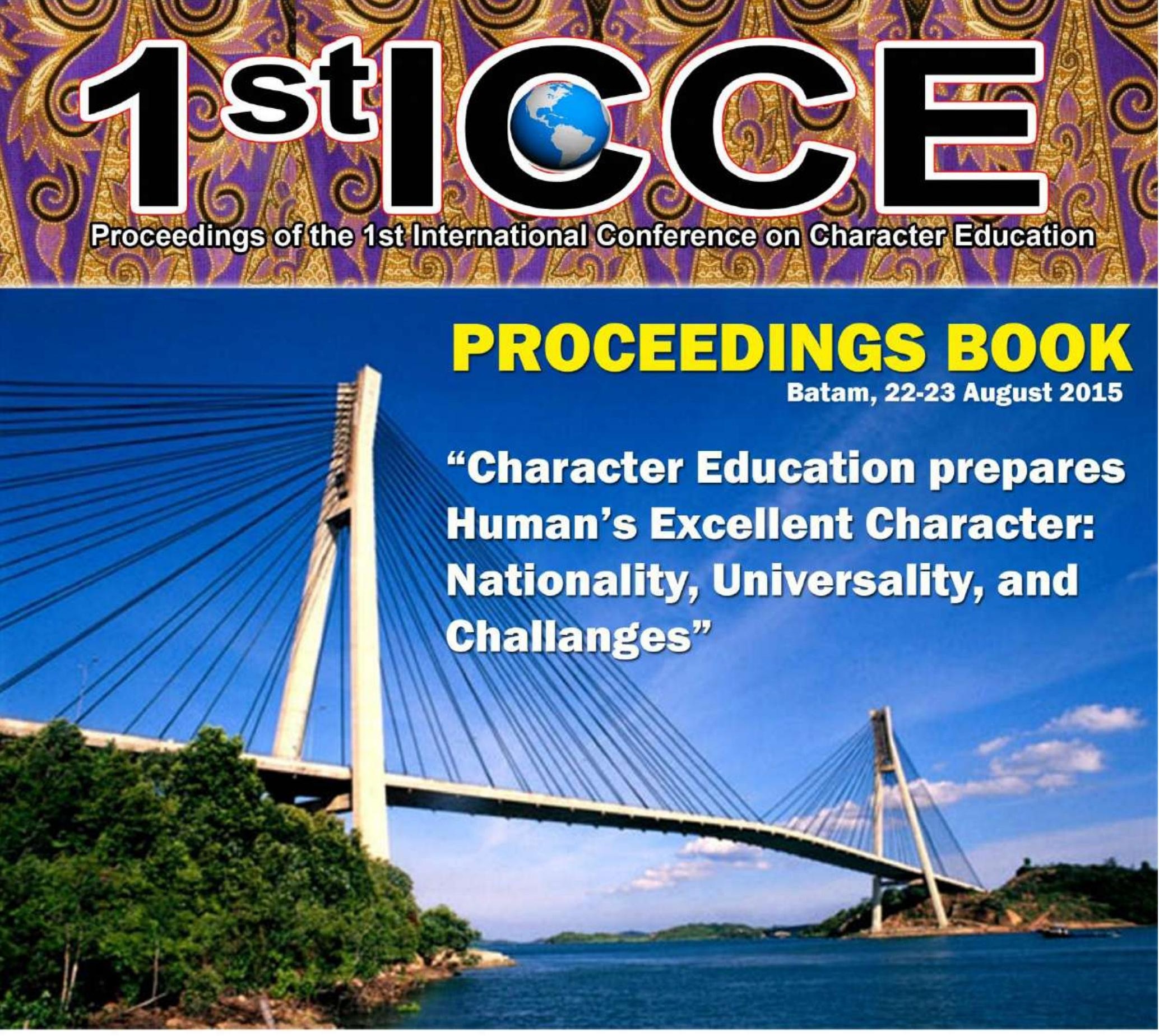

Proceedings of the 1 st international Gonference on Character Education

\title{
Organized by:
}

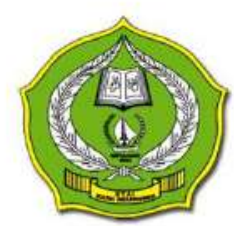

Sekolah Tinggi Agama Islam (STAI) Sultan Abdurrahman

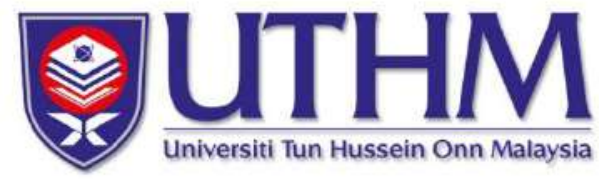

Universiti Tun Hussein Onn Malaysia (UTHM)
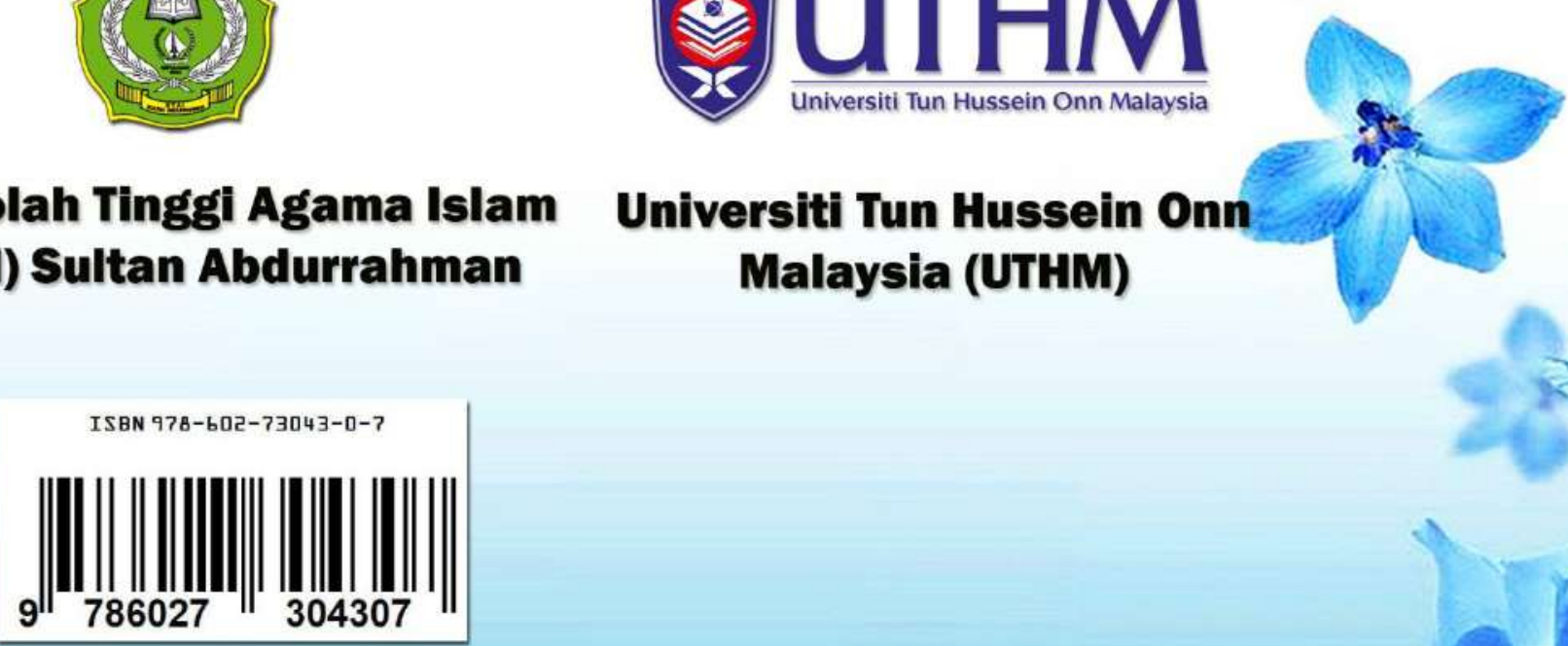
CCopyright - STAI Sultan Abdurrahman Tanjung Pinang Indonesia - 2015 Copyright Conditions All rights are reserved. No part of this publication may be reproducedstored in a retrieval system, or transmitted in any form or by any means, electronic, mechanical,

photocopying, recording, or otherwise, without the express and prior written permission of the STAI Sultan Abdurrahman.

Edited and compiled by: Alpino Susanto and Hazriyanto

Date: 1st August 2015

Publish by:

International Conference on Character Education and STAI Sultan Abdurrahman, Tanjung Pinang.

Jl. Lintas Barat KM. 19 Toapaya Bintan Kepulauan Riau

http://www.stai-sar.ac.id, contact person: Faisal 6281364736432.

International Conference on Character Education

Website: http://icce.web.id

ISBN 978-602-73043-0-?

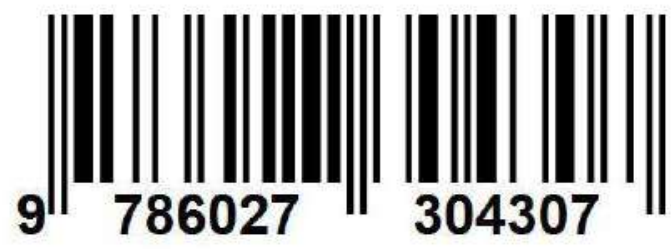

ICCE-Batam | CCopyright - STAI Sultan Abdurrahman Tanjung Pinang Indonesia 


\section{REVIEWERS}

Prof. Madya Dr Kamarolzaman Bin Mohd Jidi (Universiti Tun Hussein Onn Malaysia)

PM Dr. Razali Bin Hassan (Universiti Tun Hussein Onn Malaysia)

PM Dr. Mohd Arif Bin Agam (Universiti Tun Hussein Onn Malaysia)

Dr. Mimi Mohaffyza Binti Mohamad (Universiti Tun Hussein Onn Malaysia)

Dr. Fazlinda Binti Ab Halim (Universiti Tun Hussein Onn Malaysia)

Dr. Badaruddin Bin Ibrahim (Universiti Tun Hussein Onn Malaysia)

Dr. Md Akbal bin Abdullah (Universiti Tun Hussein Onn Malaysia)

Dr. Rafiuddin Afkari (Universiti Tun Hussein Onn Malaysia)

Puan Robijah Binti Kamarulzaman (Universiti Tun Hussein Onn Malaysia) 


\section{CONTENTS}

FOREWORD

Message from Dean of Faculty of Technical and Vocational Education (UTHM).......iv

Message from Chairman of International Conference on Character Education.......... v

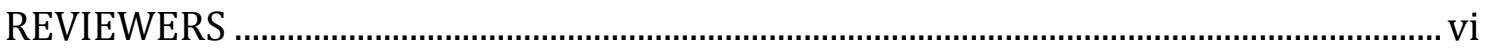

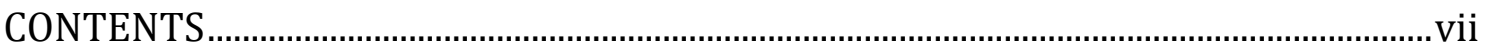

\section{TRACK 1: EDUCATION}

Competency of Integrated Living Skills Teachers in Inculcating Critical

Thinking Skill in Learning and Teaching Process................................................. 1 Rasidayanty Saion ${ }^{1}$, Siti Salwa Ab. Manap ${ }^{2}$, Jamil Abd Baser ${ }^{3}$

Student's Cognitive Level at Advanced Technology Center Batu Pahat on Development of Creativity \& Innovation.

Abdul Rahim Bin Md Tahir ${ }^{1}$, Jamil Bin Abd. Baser ${ }^{2}$

The Competence of The Integrated Living Skill Subject Teacher In Applying Communication Skill In The Process In The Process of Learning And

Teaching.

Siti Salwa binti Ab. Manap ${ }^{1}$,Rasidayanty binti Saion ${ }^{2}$, Jamil bin Abd. Baser ${ }^{3}$

An Analysis of Positive Politeness Strategies In Teaching.

Dahrul Aman Harahap ${ }^{1}$, Suswnato Ismadi Megah S ${ }^{2}$

The Profile of Teaching Skill Readiness Of Candidate Teachers Through

Micro Teaching Practice in Unrika Batam .

Sri Sugiharti

Aplications Moving Average Methods to Forecast the Number of Student SMPN 11 Batam Academic Years 2016-2020.

Tubagus Pamungkas ${ }^{1}$, Umi Rofiqoh ${ }^{2}$

A Review of Selected Theories and Their Applications to Encourage Higher

Order Thinking Skills Using the Questioning Method by Teachers . 43 Nelly Ezatul Fazlina binti Md Sah ${ }^{1}$, Siti Mizarina binti Ghazali ${ }^{2}$, Abdul Rashid bin Abdullah ${ }^{3}$,Halizah binti Awang ${ }^{4}$,

Effectiveness of Teaching and Learning Science in Higher Order Thinking Skills 21st Century: A Review Literature.

Nor Hayati binti Ismail ${ }^{1}$,Kamarolzaman bin Hj Mohd Jidi ${ }^{2}$ 
Empowering Novice Teacher Professionalism through Effective

Mentoring 65

Rosmizana Binti Yahya ${ }^{1}$, Hamidah Binti Mohamed ${ }^{2}$,Shamsiah Binti Sidek ${ }^{3}$, Yusof Bin Boon ${ }^{4}$

The Influence Factors of Teachers' Attitude When Using Computers in the Classroom: A Review.

Shamsiah binti Sidek ${ }^{1}$, Muhammad Amin bin Simon ${ }^{2}$, Rosmizana binti Yahya $^{3}$, Nor Hayati binti Ismail ${ }^{4}$, Azman bin Hasan ${ }^{5}$

Approaches in The Implementation Of Character Education. 85

Erni Munastiwi

Character Education Philosophy. Istiningsih

School Based Management in Improving The Quality Of Education. 97 Said Maskur ${ }^{1}$, Sudirman Anwar ${ }^{2}$, Syarifah Normawati ${ }^{3}$, Hardi Selamat Hood 4

Cultural Distortion When the Character Education Incessantly Towards Children of Civilized Nation Which Is Uncivilized Nation. 101 Yunisa Oktavia

Developing tolerant attitude through character education in family environment.

Sri Sumarni

The Implementation of Problem Posing Approach in Mathematic Learning on Improving Students' Logical Mathematical Thinking and Problem Solving Ability in High School.

Dahrul Aman Harahap ${ }^{1}$, Fauzan Jafri², Dwi Afrini Risma ${ }^{3}$

School Model Development Enterprise Techno to Produce Entrepreneurs among Vocational College Graduates

Hamidah Binti Mohamed ${ }^{1}$, Dr Badarudin Bin Ibrahim², Nur Bahiyah Binti Abdul Wahab ${ }^{3}$,Rosmizana Binti Yahya ${ }^{4}$

Improving Learning Motivation by Employing Library

Shabri Saleh Anwar ${ }^{1}$, Said maskur ${ }^{2}$, Alpino Susanto ${ }^{3}$, Sudirman Anwar ${ }^{4}$

A Review on Moral Values in Education and the Impact of Student

Discipline

Siti Mizarina Binti Ghazali ${ }^{1}$,Nelly Ezatul Fhazlina binti $\mathrm{Md} \mathrm{Sa^{2 }}, \mathrm{Dr}$ Yusmarwati Binti Yusof 3 
How Does University Student's Language Anxiety in Final Thesis Defense Influence Their English Speaking Ability?

Alpino Susanto, Rafiuddin Afkari, Mukmin, Amir Daus

Social factors and English achievement of junior high school students .......152 Alpino Susanto ${ }^{1}$, Kamarolzaman Bin Mohd Jidi ${ }^{2}$, Rafiuddin Afkari ${ }^{3}$, Khairudin Said $^{4}$

Evaluation On The Indonesian Language Instruction In Higher

Education .

Sri Yuliawati ${ }^{1}$, Jamil, P, Razali bin Hasan ${ }^{2}$, Rafiuddin Afkari ${ }^{3}$, Noraini binti

Kaprawi ${ }^{4}$

Excellent Character Education of Students Lecturing a Concept and its

Implementary.

Na'imah

The Handling of Juvenile Delinquency Through the Arrangement of Senior

Secondary School (SMA) Islamic Education Curriculum", aimed at

formulating the Lesson Plan.

Pudjo Sumedi ${ }^{1}$,Ihsana El Khuluqo ${ }^{2}$, Jamil ${ }^{3}$, Rogayah $^{4}$, Syarifah $^{5}$

Socio-Educational in Students' English Language Achievement . 195 Alpino Susanto ${ }^{1}$, Fazlinda Binti Ab Halim ${ }^{2}$, Rafiuddin Afkari ${ }^{3}$, Syarifa $^{4}$

Monitoring Education Problem on Coastal Society in the Small Islands Region. 205

Rianto ${ }^{1}$, Azman bin Hasan ${ }^{2}$, Md. Akbal bin Abdullah ${ }^{3}$

Character Education and Its Implementation in Guidance Counseling

Services.

Tohirin

\section{TRACK 2: ISLAMIC STUDY}

Shalat Determination Toward Employees Performance.

Chablullah Wibisono ${ }^{1}$, Hardi Selamat Hood ${ }^{2}$

Educational Characteristics of Sufi Brotherhoods. Muhammad Faisal ${ }^{1}$, Pauzi ${ }^{2}$, Rafiuddin Afkari ${ }^{3}$

An Islamic education guidance in prison: improvsing women prisoner's faith

Siti Marfuah ${ }^{1}$, Rafiuddin Afkari², Razali Hassan ${ }^{3}$, Alpino Susanto $^{4}$ 
Transformation of sufi teachings in the Malay literature sufism: effort to strengthening the character education based on local wisdom in Kepulauan Riau

Muhammad Faisal ${ }^{1}$, Rafiuddin Afkari' ${ }^{2}$ Sudanto ${ }^{3}$

Determination of faith to book of Allah towards religious performance .....261 Chablullah Wibisono ${ }^{1}$, Hardi Selamat Hood ${ }^{2}$

The Idea of Neo-Sufism and its Contribution for Humanity : A Brief Analysis

Muhammad Faisal ${ }^{1}$, Rafiuddin Afkari², Pauzi ${ }^{3}$

\section{TRACK 3:SOCIAL SCIENCES}

The Locating Pictures on a Map Activity: Developing the Young Children's Spatial Ability and Spatial Reasoning

Dahrul Aman Harahap ${ }^{1,}$ Dwi Afrini Risma ${ }^{2}$

Effect of Investment, Labor Against the Gross Domestic Product of Riau Islands Province.

Albert Gamot Malau

The Effect of Commitment and Motivation Toward Teacher's Performance at Tanjung Balai Karimun in Indonesia

Hazriyanto ${ }^{1}$, DR. Badaruddin Bin Ibrahim², Frangky33, Mu'min', Amir Daus ${ }^{5}$

The Effect of Inventory Turnover to Operating Profit Case Study at PT Astra Agro Lestari Tbk Listed on The Indonesia Stock Exchange for the Period of 2012-2014

Hazriyanto1, Mohd Arif Agam², Abd. Basith ${ }^{3}$, Rafiuddin Afkari ${ }^{4}$, Amir Daus $^{5}$

The Role of Information Communication \& Technology as enabler of Knowledge Management Process to Bring Innovation in Creative Industries (Batam Case)

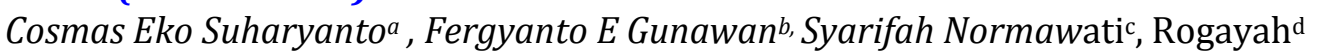

The Role Of Parliaments In Strengthening The National System Of Public Health.

Hardi Selamat Hood ${ }^{1}$, Alpino Susanto ${ }^{2}$ Hazriyanto $^{3}$

Act of analysis Number 40 In 2007 about Response Company Seen from difference listing Response Company Citizen of Indonesian toward Financial Capital Construct by Citizen of foreign (Study Case at Notary Office Andri Yuko, S.H., M.Kn)

Irene Svinarky 


\section{TRACK 4: MANAGEMENT \& LEADERSHIP}

The Development Model of $K$-Workers among Technical Graduates in

Batam Universities

Teguh Iman Santoso, ${ }^{1}$ Razali Bin Hassan ${ }^{2}$

Incentives, Discipline, and Work Unit Performance at SMP Negeri 1 Moro

on Tanjung Balai Karimun in Riau Islands Province, Indonesia.

Hazriyanto ${ }^{1}$,Badaruddin Bin Ibrahim ${ }^{2}$, Mu'min ${ }^{3}$, Frangky Silitonga ${ }^{4}$

The Effect Of Organizational Culture, Teaching Experience And Education Level Towardslecturer Professionalism At Riau Kepulauan University Academic Year 2012/2013.

Fitri Yanti

Moral Education through wearing Ihram cloth during Hajj season. 386 Erizal ${ }^{1}$, Halimi Bt. Md. Khalid², Azita Bt Ali ${ }^{3}$

Effect of Application Services of Customer Service, SMS Banking and Customer Relationship on Customer Satisfaction at PT Bank Mestika

Dharma.

Hendi Sama

Implication of Problem-Based Learning Model Learning toward

Mathematical Problem Solving Skills and Self-Regulation of SMPN 20

Students in Pekanbaru

Risnawati

Organizational Climate and Job Motivation to Job Satisfaction for PNS

Province the Archipelago of Riau.

Hazriyanto ${ }^{1}$, Khairudin Said ${ }^{2}$, Sadi Maskur ${ }^{3}$, Syarifah Normawati ${ }^{4}$, Hardi Selamat Hood $^{5}$

User Perspective Analysis DPACK-R System Yamaha 420 Heri Nuryanto, Syaifullah

Waste management environmental in Batam City.

Timbul Dompak ${ }^{1}$, Ul Qadri², Ganda Sirait ${ }^{3}$ 


\title{
The Role of Information Communication \&Technology as enabler of Knowledge Management Process to Bring Innovation in Creative Industries (Batam Case)
}

\author{
Cosmas Eko Suharyanto ${ }^{a}$, Fergyanto E Gunawan ${ }^{b}$ Syarifah Normawatic, Rogayah \\ a Binus Graduate Programs, Bina Nusantara University, Jakarta 11480, Indonesia \\ Email: costmust@gmail.com \\ bBinus Graduate Programs, Bina Nusantara University, Jakarta 11480, Indonesia \\ Email: f.e.gunawan@gmail.com
}

\section{ABSTRACT}

Information Communication \& Technology (ICT) plays an important role as a catalyst to enable and facilitate the implementation of the development, transfer, and utilization of knowledge, which subsequently may contribute to the improvement and innovation. This research intends to analyze how ICT competency directly influences knowledge management, how knowledge management directly influences innovation, and how ICT competency indirectly influences innovation through knowledge management. The research is limited to the case of the five sectors of the creative industries in the island of Batam, Indonesia. Those five sectors are television, radio, publishing, IT software and computer services, and architecture. The data are collected via questionnaire from a sample of 150 respondents. A structural equation model is established to study the interrelationship among those variables. At the end, the research concludes that ICT competency has positive effect on knowledge management, as well as on innovation via knowledge management, and knowledge management mediates the relationship between ICT competency and innovation.

Keywords: creative industries, information and communication technology, knowledge management, innovation

\section{INTRODUCTION}

Innovation is important to maintain company competitiveness [1]. It is not only for competitiveness but also to pursue long-term advantages [2,3]. Economists often cite innovation as a critical element for growth [4]. Given the importance of innovation, researchers from a variety of disciplines have focused on the answers to the critical question: "what can be done to improve innovation?", e.g., [4--7]. With the emergence of knowledge management and intellectual capital as new disciplines [8--10], scientific articles are starting to appear that add these constructs to the long list of possible antecedents of innovation, e.g., [11-13]. Along with the increasing study of knowledge management, information technology (IT) has closely been associated with the development of the great majority of knowledge management initiatives [14].

Previously, a number of scientific articles has discussed the importance of ICT competency for knowledge management, and the importance of knowledge management for innovation [14-16]. However, it is remaining a question whether an indirect relationship exists between IT competency and innovation. In work, we intend to study the indirect effect of ICT competency on innovation. Firstly, we analyze the direct relationship between ICT competency and knowledge management, and then, analyzSe the direct relationship between knowledge management and innovation. Finally, we establish the indirect relationship between ICT competency and innovation. 


\section{INNOVATION}

Innovation is generally accepted as meaning the development and implementation of new ideas [17]. Various typologies of innovation have been discussed in the literature. For example, innovation can occur at various levels within an organization: with products (what is produced), processes (how it is produced) and organizational forms (where it is produced) [18]. Alternatively, innovations can range from radical to incremental or market-pull to technology-push.

The distinction between incremental and radical innovation is important given the different effects each type of innovation is likely to have on an organization. Most innovations are incremental and will present themselves as either line extensions or modifications of existing products [19]. The ideas for these innovations are likely to come from the marketplace and so will be based on market research among current and potential customers and possibly also information about competitors and industry trends. Thus, incremental innovations are usually classified as market-pull innovations.

By contrast, a radical innovation is likely to be competence destroying, often making existing skills and knowledge redundant [20]. Additionally, radical innovations often require different management practices [21]. These innovations are more likely to originate from scientists and so are classified as technology-push innovations [22]. Radical innovations often put the business at risk because they are more difficult to successfully commercialize. However, they are considered important for long-term success as they involve the development and application of new technology, some of which might change existing market structures [23]. Radical innovations are also likely to open up opportunities for follow-on incremental improvements [24].

\section{KNOWLEDGE MANAGEMENT}

Following the conceptual framework of Lopez et. al [14], knowledge management is composed of three main processes, which are namely: knowledge generation, knowledge transfer, and knowledge codification and storage.

Knowledge generation can be defined as the process by which the firm obtains knowledge, either from outside the company or generated internally $[25,26]$. The objective is to obtain new and better knowledge that helps the organization improve its competitiveness [27]. Thus, knowledge generation is not just about generating new contents, but also about replacing, validating and updating the firm's existing knowledge [28].

Knowledge transfer refers to the process by which an organization shares knowledge among its units and members, promoting new understanding [27,28]. It is essential for the firm to develop an adequate design of informative interaction networks that allow individuals of diverse specialties, cultures, and geographic locations, not only to access the same information but also to come together through the network to undertake a particular project. Moreover, for the transfer of tacit knowledge, which requires more interaction between the individuals, the firm must develop mechanisms that encourage dialogue and interaction [29].

Finally, knowledge codification and storage is a very important aspect in the effective management of knowledge [30,31]. The existing knowledge must be captured, codified, presented and put in stores in a structured way, so it can be reused later [32]. However, it is vital to remember that organizational knowledge is dispersed and scattered throughout 
the organization. It is found in different locations, in people's minds, in organizational processes, and in the corporate culture, embedded in different artifacts and procedures, and stored in different mediums such as print, disk and optical media [33].

\section{ICT COMPETENCY}

This study defines ICT competency as how the firm uses these technologies to manage its information effectively $[14,34]$. While ICT is a generic term fundamentally used to refer to programs, computers and telecommunications, the term ICT competency is broader and refers to the use of these technologies to satisfy the firm's information needs [35]. This study differentiates between three dimensions of this concept: IT knowledge, IT operations, and IT infrastructure.

IT knowledge. Knowledge is information combined with experience, context, interpretation and reflection, so knowledge has a tacit component that is difficult to quantify [36]. Taylor [37] defines technical knowledge as the set of principles and techniques that are useful to bring about change toward desired ends. Thus, the current study defines IT knowledge as the extent to which the firm possesses a body of technical knowledge about elements such as computer systems.

IT operations. This concept refers to the IT-related methods, processes and techniques that may be needed if these technologies are to create value [38]. In the context of the current study, IT operations is defined as the extent to which the firm uses IT to improve its effectiveness and decision making.

IT infrastructure. The IT infrastructure acts as an enabler, and to a large extent is responsible for the growing interest in the production and dissemination of information [39]. IT infrastructure refers to the artifacts, tools and resources that contribute to the acquisition, processing, storage, dissemination and use of information. According to this definition, the IT infrastructure includes elements such as hardware, software and support staff.

\section{HYPOTHESIS DEVELOPMENT}

No industry, no company can stay on top without keep innovating [1]. Innovative efforts include the search for, and find, test, and development of new technologies, new products or services, new production procedures, and the new organizational structure. Innovation is about doing ideas [40]. Favorable Innovation procedure depends on the knowledge, particularly on tacit knowledge [41]. The new and valuable knowledge is created and turned into products, services and procedures [42], by converting general knowledge into specialized knowledge. In general, it can be affirmed, knowledge management, can affect the performance of the organization in a number of different ways [43]. Innovation is one of the main results of knowledge management. On the other side, ICT competency has become a central topic in the knowledge management's literature [44]. It is estimated that nearly $70 \%$ of the publications in knowledge management's focus on the design of IT systems. If innovation is one of the main results of knowledge management and ICT competency has become a central topic in knowledge management, meaning there is indirect relationship only between the ICT competency to innovation. Based on the above facts, the hypothesis:

H1. IT competency has a positive effect on the knowledge management processes

$\mathrm{H} 2 \mathrm{a}$. Knowledge management processes has a positive effect on innovation 
$\mathrm{H} 2 \mathrm{~b}$. Knowledge management processes mediate the correlation between IT competency and innovation.

\section{METHOD}

\subsection{Sample and Data Collection}

The first step in testing the above hypotheses is to choose the population object of analysis. This study focuses on five sub-sector of creative industry: architecture, radio, TV, IT software \& computer services and publishing. We used Structural Equation Modeling (SEM) to analyze the data. For the model of Structural Equation Modeling (SEM) with a variable number of construct up to five, and each construct is described by three or more indicators, the number of sample data is considered adequate 100-150 [45]. The number of samples based on the opinion of Hair, et.al [46] in Ghozali [47], the multivariate data analysis using SEM, methods of estimation using maximum likelihood estimation (MLE). MLE will be effective on the number of samples between 150-400. The number of samples can also be determined by 5-10 per parameter [48]. In this study, there are three constructs with a total of 28 parameters. Based on the above explanation, the minimum number of samples taken in this study was $5 \times 28=140$, and after the calculation of the percentage of each sub-sector, then we took 150 samples.

\subsection{Measures}

This section describes the scales used to measure IT competency, knowledge management and innovation. All the variables were measured on Likert 5-point scales ranging from $1=$ strongly disagree to $5=$ strongly agree.

IT competency. This scale was adapted from ref. [34] scale including 11 items to measure the dimensions of IT knowledge, IT operations and IT infrastructure. Items about the firm's knowledge, skills and experience in the use of IT measure the first of these dimensions. For the second dimension, the items measure the use of collaboration technologies, as well as the tools and systems available in the firm to acquire and store information that is useful in the decision making. Finally, to evaluate the firm's infrastructure, the scale includes items considering whether the firm develops software tailored to its own needs, the allocation of funds to acquire new equipment, or the existence of a person or department in charge of IT.

Knowledge management. Respondents were asked to indicate the level of agreement on each of the 11 items measuring various aspects of knowledge management processes including knowledge generation, knowledge transfer and sharing, and knowledge codification and storage. The scale was generated using some of the items from the scales proposed by [14].

Innovation. The original $[49,15]$ typology of innovation is used in this paper. Here, innovations are categorized as new to the world, new products to the firm, additions to existing product lines, improvements or revisions to existing product lines, cost reductions to existing products, or repositioning of existing products. New to the world innovations are typically characterized as radical innovations while the other categories are incremental innovations.

\section{ANALYSIS AND RESULT}

\subsection{Psychometric Properties of Measurement Scales}


Measurement model. first the authors tested the construct validity of the measures employing confirmatory factor analysis (CFA) using AMOS 21.0.0 on each variable.

Based on construct validity using confirmatory factor analysis (CFA), there are some indicators with loading factor $<0.5$ should be eliminated/dropped from construct. We concluded the measurement model, model fit using goodness of fit index and find that all the results meet the good fit values.

Structural Model. Second step of SEM is Structural Model, consists of Full Model, Normality, Outliers, Construct Reliability, and Discriminant Validity. Full Model combined all of three constructs as proposed in hypothesis development (Figure 1):

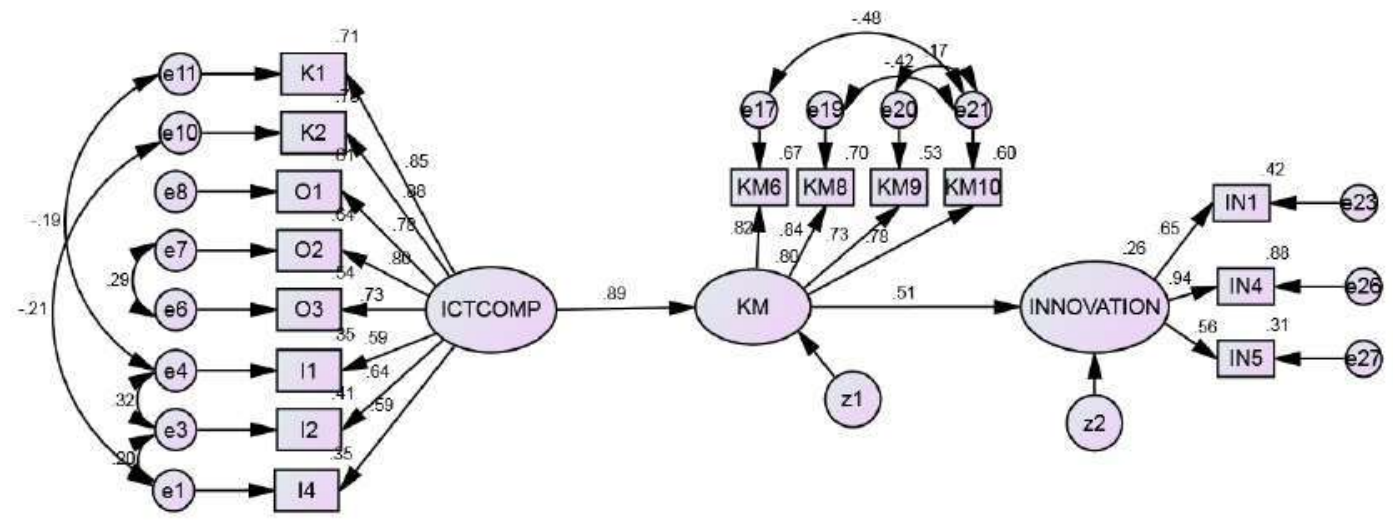

Figure 1 Full Model

Table 1Goodness of fit index test Full Model

Based on the Table 1 , Goodness of Fit Full Model is reasonable with the Chi-Square 127.420 probability $<0.05$ is 0.001 but the values of $\mathrm{DF}$, GFI, TLI, CMIN/DF, and RMSEA has met the recommended value, only AGFI has

\begin{tabular}{|c|c|c|c|}
\hline $\begin{array}{c}\text { Goodness-Of- } \\
\text { FitIndex }\end{array}$ & Cut-offValue & Model Result & Remarks \\
\hline Chi-Square & $<101,88$ & 127,420 & \multirow{2}{*}{ Bad Fit } \\
\hline Probability & $\geq 0,05$ & 0,001 & \\
\hline GFI & $>0,90$ & 0,905 & Good Fit \\
\hline AGFI & $\geq 0,90$ & 0,857 & Marginal Fit \\
\hline TLI & $\geq 0,95$ & 0,962 & Good Fit \\
\hline CFI & $\geq 0,95$ & 0,964 & Good Fit \\
\hline RMSEA & $\leq 0,08$ & 0,063 & Good Fit \\
\hline CMIN/DF & $\leq 2,0$ & 1,593 & Good Fit \\
\hline DF & $>0$ & 80 & Over Identified \\
\hline
\end{tabular}
marginal value (0.857) slightly below the recommended $\geq 0.90$.

Maximum Likelihood Estimation with observed variables requires the assumption of multivariate normality meet. Therefore, it is necessary to test to see the level in multivariate normality of the data used in this study. Evaluation of multivariate normality with Amos 21.0.0 done using the criteria of the critical ratio (cr) of Multivariate on kurtosis, if they are in the range between - 2.58 and 2.58 means that the data are multivariate normal distribution. The assessment of normality in this study results -1.790 .

Outliers are observations or data that has unique characteristics, which looks very different from the observations of others and appear in the form of extreme value, either 
for a single variable or combination of variables [47]. Detection of multivariate outliers done by looking at the value of Mahalanobis Distance. In this study shows that the data observations have mahalanobis d-squared value below 37.70 (DF 15, p < 0.001) meaning of the research has met the requirements there are no multivariate outliers.

The consistency of measuring instruments now tested. Cut-off value from Construct Reliability (CR) $\geq 0.70$ and Cut-off Value Extracted (VE) $\geq 0.50$ [49]. All measures have a composite reliability greater than the recommended level.

\subsection{Hypothesis Tests}

Hypothesis testing is performed using the value of the $t$-value with a significance level of 0.05, t-value in AMOS 21.0.0 is Critical Ratio (CR) on Regression Weights of fit model (Full Model). If the value C.R. $>1,967$ or probability value (P) $<0.05$, H0 is rejected (the research hypothesis is accepted).The results provide clear support for hypotheses $\mathrm{H} 1, \mathrm{H} 2 \mathrm{a}$, and $\mathrm{H} 2 \mathrm{~b}$. The findings show that IT competency has a positive effect on knowledge management processes (C.R. $=7.098, \mathrm{P}={ }^{* * *}$ ), Knowledge management processes has a positive effect on innovation (C.R. $=4.618, \mathrm{P}={ }^{* * *}$ ), and Knowledge Management mediates the relationship between ICT Competency and Innovation (indirect effect $=0.453$ ).

\section{DISCUSSION}

Based on the definition of creative industry, as those industries which have their origin in individual creativity, skill and talent, in the context of knowledge management, we can conclude that the creative industries are more dealing with the tacit knowledge. Knowledge and creativity have always played a relevant role in the economy [50]. As pointed out by Cunningham et al. [51], the creative industries are a high-growth sector, positively affecting jobs and economic growth. The industries of the twenty-first century will depend increasingly on the generation of knowledge through creativity and innovation [52]. But few researchers who conduct research knowledge management and innovation in the field of creative industries. This current work analyzes how the relation between knowledge management and innovation in creative industries.

Innovations emerge in this study is a radical innovation in the form of product, program or service that has never existed, or in the form of incremental innovation or such conduct improvement or improvements to the products, programs or services that already exist.

This study provides information of ICT competence factors such as IT knowledge of IT technical support staff, computer-based technical expertise, the use of IT to analyze customers, the use of decision support systems, formal MIS department, and customizable software applications will role in supporting knowledge management in the creative industries.

\section{CONCLUSION, LIMITATION}

To summarize, this study contributes empirical data to the predominantly theoretical literature on knowledge management, IT competency and innovation. It is, to a certain extent, common sense that IT has a positive impact on knowledge management and knowledge management has a positive impact on innovation. This paper takes an important step forward by analyzing how IT competency influences knowledge management directly, how knowledge management influences innovation directly, and how IT competency influences innovation indirectly through knowledge management. 
The findings of the research also have important implications for managers. Managers should not only focus on allocating sufficient resources for IT investments. Firms must focus their attention on intervening processes such as knowledge management in order to bring innovation in creative industries. Managers also need to pay more attention to the factors that can drive knowledge management, such as IT competency that will make creative industries more innovative.

The analysis described here may provide some insight into the relations between information technology competency, knowledge management, and innovation, but it suffers from some limitations. Possibly the most important limitation is the fact that the study is not providing a detailed analyze how IT affects each of the individual processes (knowledge generation, knowledge transfer, and knowledge codification and storage) in three dimensional separately.

\section{REFERENCES}

1 Zehir, Cemal, Emine Yilmaz, Harun Velioglu, The Impact of Information Technology Practice and Organizational Learning on Firm Innovation and Performance, Journal of Global Strategic Management 04, pp. 33-34, 2008

2 Hamel, Gary, Strategy Innovation and the Quest for Value, Sloan Management Review 39, pp. 7-14, 1998

3 Roberts, Rhonda, Managing Innovation: The Pursuit of Competitive Advantage and the Design of Intense Environments, Research Policy 27, pp. 159-175, 1998

4 Freeman, Chris, and Luc Soete, Te Economics of Industrial Innovation, MIT Press, 1997

5 Anderson, N. and M. A. West, The Team Climate Inventory: development of the TCI and its applications in teambuilding for innovativeness, European Journal of Work and Organizational Psychology, Vol 5 No 1, pp 53-66, 1996

6 Capon, N., J. U. Farley, D. R. Lehmann and J. M. Hulbert, Profiles of product innovators among large U.S. manufacturers, Management Science, Vol. 38 No, 2, pp 157-168, 1992

7 Cooper, R. G. and E. J. Kleinschmidt, Winning businesses in product development: critical success factors, Research-Technology Management, Vol. 39, No 4, pp 18-29, 1996

8 Bontis, N, There's a price on your head: managing intellectual capital strategically, Business Quarterly, Summer, pp. 40-47, 1996

9 Bontis, N, Intellectual Capital: an exploratory study that develops measures and models, Management Decission, Vol. 36 No. 2, pp. 63-76, 1998

10 Bontis, N, Managing Organizational Knowledge by Diagnosing Intellectual Capital: Framing and Advancing the State of the Field, International Journal of Technology Management, Vol. 18 No. 5, pp. 43-62, 1999

11 Carneiro, A., How does knowledge management influence innovation and competitiveness, Journal of Knowledge Management, Vol. 4 No 2, pp 87-98, 2000

12 Dove, R., Knowledge management, response ability, and the agile enterprise, Journal of Knowledge Management, Vol. 3 No 1, pp 18-35, 1999

13 Nonaka, I. and H. Takeuchi, The knowledge-creating company. Oxford University Press, NY, 1995

14 López, Susana Pérez., Peón, José Manuel Montes., and Ordás, Camilo José Vázquez, Information Technology as an Enabler of Knowledge Management: An Empirical Analysis, Department of Business Administration, University of Oviedo, Avda. del Cristo, s/n 33071, Oviedo, Spain, 2009

15 Darroch., Jenny, Knowledge management, innovation and firm performance, Journal of Knowledge Management Vol. 9 NO. 3, pp.101-115, 2005 
16 Omona, W., van der Weide, T., and Lubega, J, Using ICT to enhance Knowledge Management in higher education: A conceptual framework and research agenda, International Journal of Education and Development using Information and Communication Technology (IJEDICT), 6 (4), pp. 83-101, 2010

17 Van de Ven, A. H., Central problems in the management of innovation, Management Science, Vol. 32 No, 5, pp 590-607, 1986

18 Chandrashekaran, M., R. Mehta, R. Chandrashekaran and R. Grewal, Market motives, distinctive capabilities, and domestic inertia: a hybrid model of innovation generation, Journal of Marketing Research, Vol. 36 No 1, pp. 95-112, 1999

19 Dosi, G., Sources, procedures and microeconomic effects of innovation, Journal of Economic Literature, Vol. 26, September, pp. 1120-1171, 1988

20 Tushman, M. and P. Anderson, Technological discontinuities and organizational environments, Administrative Science Quarterly, Vol. 31, pp. 439-465, 1986

21 O'Connor, G. C., Market learning and radical innovation: a cross case comparison of eight radical innovation projects, Journal of Product Innovation Management, Vol. 15, pp. 151-166, 1998

22 Workman Jr, J. P., Marketing's limited role in new product development in one computer systems firm, Journal of Marketing Research, Vol. 30, November, pp. 405421,1993

23 Green, S. G., M. B. Gavin and L. Aiman-Smith, Assessing a multidimensional measure of radical innovation, IEEE Transactions on Engineering Management, Vol. 42 No, 3, pp. 203-214, 1995

24 Veryzer Jr., R. W., Discontinuous innovation and the new product development process, Journal of Product Innovation Management, Vol. 15, pp. 304-321, 1998

25 Lee, S.M., and S. Hong., An enterprise-wide knowledge management system infrastructure, Industrial Management \& Data Systems 102(1): 17-25, 2002

26 McCann, J.E., and M. Buckner., Strategically integrating knowledge management initiatives, Journal of Knowledge Management 8: 47-63, 2004

27 Wiig, K.M., Integrating intellectual capital and knowledge management, Long Range Planning 30(3): 399-405, 1997

28 Alavi, M.L., and D.E. Leidner., Review: Knowledge management and knowledge management systems: Conceptual foundations and research issues, MIS Quarterly 25(1): 107-136, 2001

29 Gherardi, S., and D. Nicolini., Learning in a constellation of interconnected practices: Canon or dissonance?, Journal of Management Studies 39(4): 419-436, 2002

30 Casey, A., Collective memory in organizations, Advances in Strategic Management 14: 444-446, 1997

31 Cross, R., and L. Baird., Feeding organizational memory: Improving on knowledge management's promise to business performance. In Strategic learning in a knowledge economy. Individual, collective and organizational learning process, ed. L. Robert, J. Cross, and S.B. Israelit, 69-90. Oxford: Butterworth-Heinemann, 2000

32 Choi, B., S.K. Poon, and J.G., Effects of knowledge management strategy on organizational performance: A complementarity theory-based approach, Omega 36: 235-251, 2008

33 Bhatt, G.D., Knowledge management in organisations: Examining the interaction between technologies, techniques and people, Journal of Knowledge Management 5(1): 68-75, 2001

34 Tippins, M.R., and R.S Sohi., TI competency and firm performance: Is organizational learning a missing link?, Strategic Management Journal 24(8): 745-761, 2003 
35 Gunasekaran, A., P. Love, F. Rahimi, and R. Miele., A model of investment justification in information technology projects, International Journal of Technology Management 21: 349-364, 2001

36 Davenport, T.H., and L. Prusak, Working knowledge: How organisations manage what they know, Boston, MA: Harvard Business School Press, 1998

37 Taylor, J.C., Technology and planned organizational change, Ann Arbor, MI: BraunBrumfield, 1971

38 Maier, J.L., R.K. Rainer, and C.A. Snyder., Environmental scanning for information technology: An empirical investigation, Journal of Management Information Systems 14(2): 177-201, 1997

39 Reardon, J., R. Hasty, and B. Coe., The effect of Information technology on productivity in retailing, Journal of Retailing 72(4): 445-461, 1996

40 Borghini, S. (2005). Organizational creativity: Breaking equilibrium and order toinnovate. Journal of Knowledge Management, 9(4), 19-33.

41 Leonard, D, \& Sensiper, S. (1998). The role of tacit knowledge in group innovation.California Management Review, 40(3), 112-132.

42 Choy, C. S., Yew, W. K., \& Lin, B. (2006). Criteria for measuring KM performanceoutcomes in organizations. Industrial Management \& Data Systems, 106(7),917-936.

43 Von Krogh, G., Ichijo, K. and Nonaka, I. (2000), Enabling Knowledge Creation, Oxford University Press, New York.

44 Hayes, M.; Walsham, G. (2003). "Knowledge sharing and ICTs: A relational perspective". In Easterby-Smith, M.; Lyles, M.A. The Blackwell Handbook of Organizational Learning and Knowledge Management. Malden, MA: Blackwell. pp. 54-77. ISBN 978-0-63122672-7.

45 Santoso, Singgih, Structural Equation Modeling, Konsep dan Aplikasi dengan Amos 18.0, PT. Elex Media Komputindo, Jakarta, 2011

46 Hair, J. F., Jr., Anderson, R. E., Tatham, R. L. and Black, W. C. Multivariate Data Analysis, 3rd ed, Macmillan Publishing Company, New York, 1995

47 Ghozali, Imam, Model Persamaan Struktural, Konsep dan Aplikasi dengan Program Amos 16.0, Badan Penerbit Universitas Diponegoro, Semarang, 2008

48 Haryono, Siswoyo, Parwoto Wardoyo, Structural Equation Modeling, Untuk Penelitian Manajemen Menggunakan Amos 18.0.0, PT. Intermedia Personalia Utama, Bekasi, 2012

49 Booz Allen Hamilton., New Products for the 1980s, Booz Allen Hamilton, New York, NY, 1982

50 Porlezza, C. \& Colapinto, C., Innovation in Creative Industries: From the Quadruple Helix Model to the Systems Theory, Journal of the Knowledge Economy, 3(4), pp. 343353,2012

51 Cunningham, Stuart, Ryan, Mark David, Keane, Michael \& Ordonez, Diego., Financing Creative Industries in Developing Countries, in Diana Barrowclough and Zeljka KozulWright eds, Creative Industries and Developing Countries: Voice, Choice and Economic Growth, Routledge, London and New York, pp. 65-110, 2008

52 Landry, Charles; Bianchini, Franco, The Creative City, Demos, 1995. 


\section{Organized by}

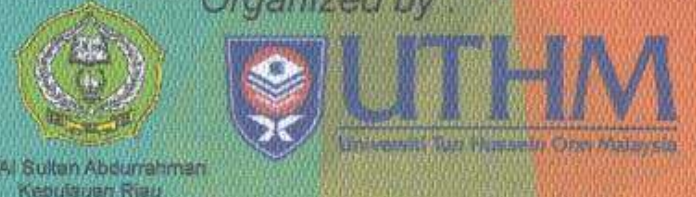

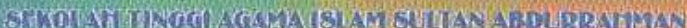
Repirauan stiu InGonesta

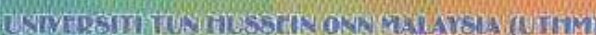

\section{ICCE}

0 (2) 80 웅요
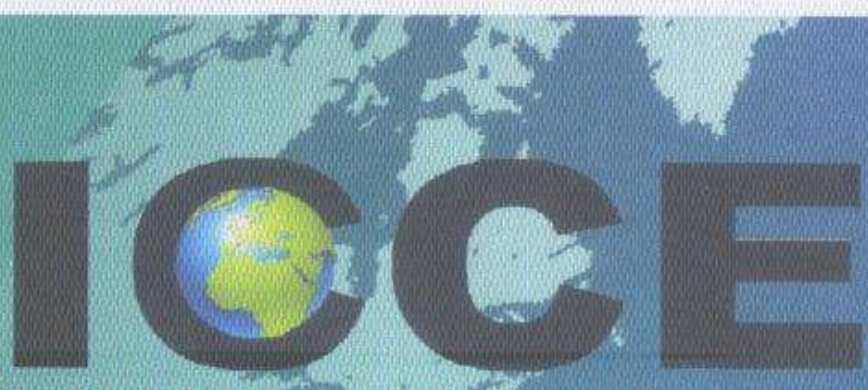

1st International Confererice on Chäracier Education (ICCE) 2015 CERTIIFCANIE OF APRECIATION

THIS CERTIFICATE IS AWARDED TO Gormas Eko OSuhaminto

For the role as PRESENTER

in

1st The International Conference on Character Education (ICCE-2015)

August 22 - August 232015 Vista Hotel, Batan, INDONESIA

Assoc. Prof bruRazali Hassan Dean, Faculty of Technical and Vocationat Education Universiti Tun Hussein Orn Malaysia

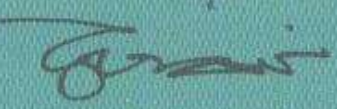

Dr. In. Chabiullah Wibisono, MM Chairman 